Revista de Psicología Vol. 35 (2), 2017 (ISSN 0254-9247)

\title{
At-Risk Latin American Youth: Challenges to Change
}

\author{
Judith L. Gibbons ${ }^{1} \&$ Katelyn E. Poelker ${ }^{2}$ \\ Saint Louis University - USA
}

\begin{abstract}
Fostering the well-being of Latin American and Caribbean youth is vital to the region's success. Despite their significant presence in the population, many youth face extraordinary challenges, such as poverty, exposure to violence, and lack of access to quality education. We review some successful interventions from an ecological perspective that address the needs of at-risk youth in the region. Interventions in a variety of countries have been aimed at altering the microsystems or ecosystems of youth as well as involving them directly. Direct interventions with youth must involve them in meaningful activities that provide a sense of empowerment. The lessons learned from these interventions reveal the outstanding potential of youth to thrive despite the obstacles they face.
\end{abstract}

Keywords: at-risk youth, interventions, Latin America, empowerment.

\section{Jóvenes latinoamericanos en riesgo: Los desafíos para lograr el cambio}

Fomentar el bienestar de los jóvenes de Latinoamérica y el Caribe es vital para lograr el éxito en la región. A pesar de que tienen una presencia significativa en la población, muchos jóvenes enfrentan desafíos extraordinarios, tales como la pobreza, la exposición a la violencia y la falta de acceso a una educación de buena calidad. Hacemos una revisión desde una perspectiva ecológica de algunas intervenciones que abordan las necesidades de los jóvenes en riesgo en la región. Las intervenciones en una gama de países se enfocan en alterar los micro sistemas o ecosistemas de la juventud, así como involucrar a los jóvenes directamente. La intervención directa con los jóvenes debe involucrarlos en actividades que tienen sentido para ellos y brindarles empoderamiento. Las lecciones aprendidas a partir de estas intervenciones revelan el potencial excepcional de la juventud para prosperar a pesar de los obstáculos que afrontan.

Palabras clave: jóvenes en riesgo, intervenciones, Latinoamérica, empoderamiento.

$1 \quad \mathrm{PhD}$. in Psychology. Emeritus Professor at Saint Louis University. Postal address: Department of Psychology, Saint Louis University, 3700 Lindell Boulevard, Saint Louis, MO 63108. Contact: gibbonsjl@slu.edu

$2 \mathrm{PhD}$ in Psychology at Saint Louis University. Postal address: Department of Psychology, Saint Louis University, 3700 Lindell Boulevard, Saint Louis, MO 63108. Contact: kpoelke1@slu. edu 


\section{Juventude latino-americana em risco: Desafios para a mudança}

Promover o bem-estar dos jovens na América Latina e no Caribe é vital para o sucesso na regiáo. Apesar de ter uma presença significativa na população, muitos jovens enfrentam desafios extraordinários como a pobreza, a exposição à violência ea falta de acesso à educação de qualidade. Nós revisamos a partir de uma perspectiva ecológica de algumas intervençôes que abordam as necessidades dos jovens em risco na região. Intervençóes em uma série de países foco em micro sistemas ou alterando ecossistemas jovens e envolver os jovens diretamente. Intervençáo direta com os jovens devem participar de atividades que fazem sentido para eles e fornecer capacitação. As liçóes aprendidas com essas intervençóes revelam o potencial excepcional de jovens a prosperar, apesar dos obstáculos que enfrentam. Palavras-chave: jovens em risco, as intervençôes, a América Latina, a capacitação. 
"Adolescence is a pivotal time .... to help [youth] navigate risks and vulnerabilities, and to set them on the path to fulfilling their potential" (United Nations International Children's Emergency Fund [UNICEF], 2011). Adolescents and youth, their well-being in the present and for future, are of critical importance in Latin America and the Caribbean. The region is young demographically and issues pertaining to youth must be adequately addressed for the region to thrive. There are 108 million youth ages 15-24 in Latin America and the Caribbean (Organización Internacional del Trabajo [OIT], 2013). In 2015 , nearly one-fifth (18\%) of the region's population was between the ages of 10 and 18 (UNICEF, 2016). Unfortunately, many of the young people in Latin America face a host of challenges that threaten the opportunity for their healthy development. Many of those challenges are rooted in poverty and a lack of resources, including high rates of juvenile delinquency, adolescent pregnancy, and exposure to violence (e.g., physical, sexual, and gangs). The purpose of this article is to describe the risks facing adolescents and youth of Latin America, as well as a select sample of interventions that have been implemented to better the lives of at-risk Latin American youth. All of these programs have been systematically evaluated for their effectiveness. They represent a wide range of interventions, including non-violent horse handling workshops in Guatemala, lengthening the school day in Chile, preventing HIV/AIDS in Mexico, providing vocational training to address unemployment in Colombia, increasing school attendance in Nicaragua, and engaging adolescents as tutors for younger students in Brazil. Using ecological systems theory, we review the commonalities and differences among the interventions, and propose future directions for improving the well-being of at-risk youth of Latin America. 


\section{Bronfenbrenner's Ecological Systems Theory}

It is important to consider the influences on development, both proximal (e.g., parents) and distal (e.g., the values of the culture), when describing the challenges facing at-risk youth. One framework commonly used to understand the role of environment in the lives of youth is Bronfenbrenner's $(1977,1979)$ ecological systems theory. In this model, the young person's world is shaped by multiple layers of systems and the interactions among those systems with the individual at the center. Microsystems are those closest in proximity to the youth and they are settings in which the adolescent personally participates. Examples of microsystems include family members and friends, as well as the adolescent's school, church, and neighborhood. Mesosystems reflect interaction of the various microsystems, for example, when parents talk with teachers about the adolescent's academic performance. Exosystems are systems that adolescents do not directly participate in but do have direct bearing on their lives. Friends' parents, their local school board and neighborhood associations, and legal and social welfare services represent different exosystems. Finally, the macrosystem, the most distal from the youth, consists of the worldview and values supported by the adolescent's culture as reflected in the media and political and economic structures. The chronosystem was added later to represent the role of socio-historical circumstances in development (Bronfenbrenner, 2005). For example, economic recessions and periods of wartime can have profound effects on human development.

Although numerous models have been proposed to frame child and adolescent development, Bronfenbrenner's approach, like Vygotsky's (1978), incorporates the role of culture and the environment as major factors in shaping the growth of young people. Furthermore, ecological systems theory conceptualizes development as an interaction among factors at various levels of the environment. An example of one such interaction comes from a study on parenting practices and violence in El Salvador (Rojas-Flores et al., 2013). Parents who had been exposed to community violence themselves reported an increased value for 
family and life and emphasized meaning making. Those parents also were overprotective of their children and modeled negative coping behaviors. In other words, development is a function of the individual and the environment in which he/she lives and has lived.

Bronfenbrenner's model can be aptly applied to at-risk youth. Take gang violence, for example, a reality that propels many Latin American youth into a life of violence. Estimates of the numbers of gang members fluctuate wildly with researchers estimating between 25,000 and 125,000 members in Guatemala, El Salvador, and Nicaragua alone (UNICEF, n.d.) Youth are disproportionately and doubly impacted as both perpetrators and victims of gang violence; young men are particularly at risk to be both victims and aggressors (Imbusch, Misse \& Carrión, 2011). The countries of Central America, in particular, continue to face great challenges with the growth of youth gangs.

In applying Bronfenbrenner's model to adolescents involved in gangs, some individual variables elevate the risk for gang violence like gender and age (both men and later adolescents/young adults are more susceptible to the gang membership compared to women and early adolescents). In the microsystem, peers and neighborhood play an important role in shaping the daily activities of youth. We know that during adolescence peers play an increasingly important role in adolescents' decision making, from their views on material possessions (Gil, Kwon, Good \& Johnson, 2012) to risk-taking

(Chein, Albert, O’Brien, Uckert \& Steinberg, 2011), so it is not surprising that they can influence participation in gang violence. With respect to neighborhoods, research suggests that gangs thrive in urban areas (Imbusch et al., 2011). In Latin American cities, poverty, inequality, and violence abound; research from Mexico shows that income inequality is associated with higher homicide rates (Enamorado, López-Calva, Rodríguez-Calaván \& Winkler, 2014).

The mesosystem, according to Bronfenbrenner (1977, 1979), refers to the relation between and among the various components of microsystems. For example, groups of peers could gather in a neighborhood park to meet about or plan gang activities. Here, two components 
of the microsystem (i.e., peers and neighborhood) interact. In the exosystem, the creation of a neighborhood watch program could deter gang-related activities and violence. The broader macrosystem includes the values of the culture, but also the government, for example. If the government is not actively working to decrease gang violence or prosecute the offenders, the adolescent might conclude that violence is valued, or at least not actively discouraged. The media may also reinforce those attitudes by glorifying violence. In addition, creating employment opportunities for youth maybe an effective way to decrease risks (Cárdenas, de Hoyos \& Székely, 2011). Finally, the chronosystem, or the socio-historical period in which the adolescent is developing, reflects the overarching events that define that historical period. With respect to gang violence, the chronosystem may be reflected in the finding that Latin America is currently the most dangerous region of the world; in 2013, for every three murders worldwide, one occurred in Latin America (Murray, 2014).

\section{Existing Interventions for At-Risk Youth}

To illustrate some of the central risks adolescents face and the efforts in place to address those challenges, we have selected a series of six empirically evaluated interventions designed specifically for Latin American adolescents.

\section{Non-Violent Horse-Handling Workshops in Guatemala}

Violence, in the roles of both victim and perpetrator, is a major risk for Latin American youth. Children and adolescents living in Latin America and the Caribbean have a greater chance of dying at the hands of homicide than in any other region in the world (UNICEF, 2014). When ordering individual countries on youth homicide rates, the top three countries are all located in Latin American: El Salvador, Guatemala, and Venezuela, respectively, while Cuba, Peru, and Suriname boast significantly lower figures (UNICEF, 2014). Around the world, 
boys, particularly those in late adolescence (ages 15-19) are at elevated risk as victims of homicide compared to girls (UNICEF, 2014). In seven countries in the region (Panama, Venezuela, El Salvador, Trinidad and Tobago, Brazil, Guatemala, and Colombia) homicide is the leading cause of death among adolescent boys (UNICEF, 2014).

Homicide is, of course, an extreme form of violence. Many Latin American youth experience less severe forms of violence daily. For example, violent discipline in the home is common; of the 12 Latin American and Caribbean countries with available data, in 10 of those countries, approximately 50 percent of children experience violent discipline at home (UNICEF, 2014). Rates are lowest in Costa Rica and Panama. Physical altercations with peers are also frequent; in general, boys are more likely to engage in physical altercations than girls (UNICEF, 2014). When 13-15-year-old boys were asked if they had participated in a physical fight at least once in the last year, over $50 \%$ of boys in Peru answered affirmatively (UNICEF, 2014). Girls in the region report relatively high rates of physical fights as well (Fries, Grogan-Kaylor, Bares, Han \& Delva, 2013). When asked how many had been robbed in that same time frame, just over $50 \%$ of sixth graders across those 16 countries answered affirmatively, with the highest rate reported in Colombia (55\%) and the lowest in Cuba (11\%). Other forms of violence among adolescents, such as bullying, also appear pervasive in Latin America and the Caribbean. Approximately half of sixth graders in 16 Latin American and Caribbean countries reported being bullied in the last month with a high of $63 \%$ in Colombia and a low of 13\% in Cuba (Román \& Murillo, 2011). Sixteen percent indicated they had been physically bullied.

A recent intervention with at-risk youth in Guatemala implemented a non-violent horse-handling intervention to boost leadership and foster emotion regulation, while decreasing aggressive attitudes and behaviors (Gibbons, Cunningham, Paiz, Poelker \& Chajón, 2016). Adolescents and young adult participants (ranging in age from 15-23) in this mixed-methods study were selected at the recommendation of the school psychologist because they had experienced violence in the 
home, frequently aggressed others, or were withdrawn and depressed, among other concerns. Using a wait-list control group design, youth participated in a 2-day workshop with a series of interactions with horses and other activities including deep breathing exercises. A core element of these workshops was a Join- $\mathrm{Up}^{\circledR}$-inspired experience based on the work of horse trainer Monty Roberts (Roberts 2002a, 2000b). During a Join- $\mathrm{Up}^{\circledR}$, the horse and his/her handler learn to communicate non-violently. In other words, the horse comes to follow the human handler without the use of physical force. Horses were used in these workshops because of their keen ability to read and respond to people's non-verbal behavior (Keeling, Jonare \& Lanneborn, 2009) and emotions (Smith, Proops, Grounds, Wathan \& McComb, 2016).

At post-test, participants reported higher levels of leadership ability on a quantitative measure. Participants' mentors reported lower levels of aggression. In focus groups, both family members and the participants themselves noted better emotion regulation abilities, despite non-significant quantitative post-test differences on traditional emotion regulation scales. In the focus groups, participants explained that they commonly used the breathing exercises they learned in the workshops to calm themselves during a conflict. Youth anecdotes of empowerment complemented the quantitative reports of increased leadership abilities. Participants also reported feeling positive emotions (e.g., happiness) more frequently and negative emotions less frequently (e.g., fear) following the workshops.

Family members suggested that what their children and siblings learned through the horse workshops was shared with other members of the family suggesting the program may have a "ripple effect." Relatives also noticed increases in confidence and leadership at home with one mother commenting about her son's experience leading the horse, "...now he will be the leader of the house" (Gibbons et al., 2016, p. 11). Finally, family members noticed less hostile and more compassionate interactions between participants and close others; some attributed this, at least in part, to participants' newly acquired ability to trust others. 
Although these horse-handling workshops appear to have benefitted at-risk Guatemalan youth by empowering them to be more confident leaders and less aggressive toward peers, the specific mechanism by which the intervention was effective remains unknown. In other words, we have been unable to isolate the exact mechanism (or combination of mechanisms) that make these workshops so beneficial for youth. For example, is it the general interaction with horses, the Join- $\mathrm{Up}^{\circledR}$-inspired experience, or the breathing exercises that contribute to participant benefits? Another likely possibility is the care and attention participants received throughout the course of the workshops. That is, youth experienced high levels of social support first-hand throughout the workshops as adults took an active interest in what they were thinking and feeling. Further research is necessary to better understand why it is that these horse-centered workshops promote leadership and emotion regulation among youth, while reducing aggression and violence.

A central feature of this study is that participants were randomly assigned to either the experimental or wait-list control group allowing researchers to conclude that it was the workshops that made the difference in participants' increased leadership and decreased aggression as opposed to other factors unrelated to the study. Despite this critical contribution to the literature, the study's small and homogenous sample leaves room for improvement. For example, all of the participants were living in poverty. Although that was the target group in the Gibbons et al. (2016), those sample characteristics may limit the generalizability of the findings.

\section{Extending the School Day to Reduce Risky Behavior in Chile}

A study from Chile suggests that one simple adjustment to adolescents' daily schedules — making the school day longer — significantly decreased teenage pregnancy and crime (Berthelon \& Kruger, 2011). Adolescent pregnancy is a well-documented problem in Latin America and the Caribbean; $18 \%$ of babies born to adolescents worldwide are born in the region (World Health Organization [WHO], 2014). 
In Nicaragua, $28 \%$ of girls give birth before the age of 18 (United Nations Population Fund [UNFPA], 2013). Despite evidence for a general global decline in teen pregnancies (defined as girls under age 18), recent data from Latin America and the Caribbean do not follow that trend (UNFPA, 2013). In general, adolescents from economically disadvantaged families are more likely to experience early pregnancy than girls from wealthier families; the economic disparity is more exaggerated in Latin American and the Caribbean than in any other region in the world. Adolescent girls in the poorest $20 \%$ of households are nearly five times as likely to become pregnant than girls in the richest $20 \%$ of households (UNFPA, 2013). Furthermore, girls living in rural areas and who have completed fewer years of education are also particularly at-risk for becoming teenage mothers (UNFPA, 2013).

The consequences of becoming a mother at a young age are multifaceted, with education and maternal health among those most commonly discussed. Oftentimes the adolescent mother drops out of school and never returns to complete her education (UNICEF, 2007). In Jamaica, although adolescent mothers are entitled to an education by law, in reality many are forced by the schools to drop out or are expelled if still enrolled when the school learns the girl is pregnant (UNICEF, 2007). With girls ages 10-19 comprising nearly 20\% of the population in Latin America and the Caribbean in 2010, issues related to young women's health should be paramount (UNFPA, 2013). Teenage pregnancy is a significant risk to the mother's physical health (and the baby's as well); complications from pregnancy and childbirth are the second leading cause of death globally for girls ages 15-19 (WHO, 2014). Fortunately, however, adolescent maternal health has been improving since 2000 (WHO, 2014). When asked why they become pregnant so young, many girls cite peer pressure and curiosity (UNICEF, 2007). When Latin American adolescents were asked how teen pregnancy may be combatted, young people emphasize better sex education with less focus on abstinence and more on how to have safe, protected sex (UNICEF, 2007). Both educational and health-related 
consequences of teen pregnancy and motherhood have long-lasting impacts for young woman, their children, and their communities.

Another risky behavior, juvenile delinquency, is commonly associated with exposure to violence described above (UNICEF, 2008b). Youth exposed to violence, including violent discipline and those who act as bullies, are at an increased risk for engaging in future criminal behavior (UNICEF, 2008b). Moreover, crime is a gateway to a host of other negative outcomes (e.g., homelessness, incarceration; United Nations [UN], 2003) and unfortunately, juvenile delinquency is increasing in almost all Latin American countries (Munyo, 2013). Although lower poverty rates are associated with lower crime rates, this increase has occurred despite overall declines in poverty (Muggah, 2015). One explanation for this finding is that the incentives to commit crimes are increasing (Munyo, 2013). In Uruguay, for example, a combination of factors including insufficient law enforcement to punish offenders, an increase in escapes from delinquency facilities, a rising cocaine epidemic, and a more permissive law for juvenile delinquents resulting in softer punishments have contributed to this increase. Other explanations include: inequality, high rates of youth unemployment, high rates of ninis (from the Spanish phrase ni estudia ni trabaja meaning "neither studying, nor working"), weak and corrupt law enforcement and justice systems, and high rates of organized crime (e.g., drug trafficking, de Hoyos, Rogers, Székely, 2016; Muggah, 2015). Although there is oftentimes a lack of trust between the police/law enforcement and young people, establishing that confidence between the two groups is a necessary step to reduce delinquency (United Nations Development Programme [UNDP], 2013).

In Chile, a nationwide effort known as full-day school reform (FDS) that began in 1997 resulted in a weekly increase of almost 22\% of the time youth spend in school (Berthelon \& Kruger, 2011). In more practical terms, students now spend 7 more hours in school each week for a total of 39 hours weekly. The increase was driven in large part by the requirement that students must remain on campus until $4 \mathrm{pm}(16: 00)$ at least some days each week; in the past, students were 
dismissed each day at $1 \mathrm{pm}$ (13:00). The lengthening of the school day represents an exosystem level intervention according to Bronfenbrenner's $(1977,1979)$ model.

Although the FDS program was originally instituted to boost scores on standardized tests, it appears the impact on adolescents' social worlds, particularly rates of adolescent risk-taking behaviors, is more robust. More specifically, this school day extension means that youth spend a greater part of the day under adult supervision, presumably decreasing the opportunity to engage in risky behaviors. With respect to adolescent motherhood, rates of adolescent pregnancy decreased by $24 \%$ following the intervention. Lengthening the school day has been most beneficial for girls living in poverty and in an urban setting. The authors argue that this boost for young girls in such disadvantaged circumstances may provide a partial solution to the inequalities that plague underprivileged young women with respect to future employment (Berthelon \& Kruger, 2011). Lengthening the school day was also effective in combatting crime with decreases in both violent and property crimes. Crime was measured at the municipal level. Examples of municipal crime include assault and trespassing. Overall, results indicated a $17.5 \%$ decrease in crime at the municipal level, with the intervention particularly successful in lowering property crime rates (a decrease of 22\%). Violent crimes fell by $12 \%$. These results held both for both boys and girls. In sum, this intervention suggests that providing youth with a safe alternative to spending their time unsupervised is effective in reducing two forms of adolescent risky behavior.

\section{HIVIAIDS Prevention Programs in Mexico}

In addition to adolescent pregnancy, the spread of HIV/ AIDS remains a significant health concern for Latin American and Caribbean youth. Adolescents stand to be doubly affected by HIV/ AIDS because they can become infected themselves and because they may lose a mother, father, or both parents to the disease (UNICEF, 2008a). Although commonly addressed in discussions of at-risk youth 
in African (specifically sub-Saharan African) countries, Latin America and the Caribbean youth also affected by the AIDS epidemic. In 2013, there were approximately 1.6 million people in Latin America living with HIV (Avert, 2016). Nearly 740,000 of these cases were reported in youth ages 15-24 (UNICEF, n.d.). The situation is arguably more serious in the Caribbean, which has the second highest HIV/AIDS rate in the world, second only to sub-Saharan Africa (UNICEF, n.d.) Fifteen to 24-year-old youth represent approximately half of all new cases each year in Latin America with the number reaching 60\% in the Caribbean (UNICEF, n.d.). More specifically, over 34,000 new cases of HIV/ AIDS were reported in 2011 among young people in Latin America ages 15-24 (UN AIDS, 2012). That same year, nearly 2000 babies were born with HIV. Young women in the region are disproportionately affected. In Barbados, for example, the rate of HIV/AIDS infection is between three to six times higher for young women than it is for young men (UNICEF, n.d.) Rate of infection varies greatly by country with Brazil responsible for $46 \%$ of all new HIV/AIDS cases reported across all ages in 2013 (Avert, 2016). In comparison, the number of new cases was considerably lower in Paraguay and Chile (2\% each in 2013). Fortunately, however, recent estimates suggest that the prevalence of HIV/AIDS in the region is on the decline (UN AIDS, 2015).

HIV/AIDS is closely connected to other pressing issues for Latin American and Caribbean youth. Like those issues, HIV/AIDS carries a stigma and HIV positive youth fear being bullied or ostracized. A quote from Oaku, an HIV positive 18-year-old from Colombia, reveals some of the challenges youth face with respect to AIDS,

Many young people believe that by standing next to someone you can catch HIV/AIDS. At school I didn't say anything to anybody and people would say, 'I don't know anyone who has HIV/AIDS, and I'd be sitting right there beside them.' (UNICEF, 2008a, p. 3)

Groups like Jovenes Positivos [Network of Positive Youth] are dedicated to providing young people affected by HIV/AIDS with health care services and treatment that are specifically designed for a 
adolescents and young adults (UN AIDS, 2012). The group designed a survey for young people to address their specific needs for health care services and the social aspects of living as someone infected with HIV (e.g., incidents of discrimination and community participation related to HIV/AIDS issues). This effort supports previous calls to design youthspecific HIV/AIDS treatment (UN AIDS, 2015; UNICEF, 2008a). Furthermore, a lack of education and understanding of reproductive health in youth may perpetuate the stigma that has surrounded the epidemic for centuries. However, recent efforts in Latin America have been focused not only on being more youth-friendly, but also to be more inclusive of the LGBTQI (Lesbian, Gay, Bisexual, Transgender, Queer/Questioning, and Intersex) community (UN AIDS, 2015). Those efforts represent an initiative to change the broader cultural values towards individuals frequently affected by this epidemic.

A program aimed at preventing HIV infection in Mexican secondary school students ( $10^{\text {th }}$ graders) was implemented by Givaudan and colleagues (Givaudan, Van de Vivjer, Poortinga, Leenen \& Pick, 2007). The program, devised specifically for adolescents, was evaluated based on three primary outcomes: personal variables (e.g., self-efficacy related to condom use), intervening variables (e.g., understanding of HIV/AIDS), and outcome variables (e.g., intention to use condoms). It was based in part on another initiative, Planeando tu Vida [Planning your Life], that has been used for many years with this population (see Pick de Weiss et al., 1988).

Schools were randomly assigned to either the experimental or control conditions. In the experimental condition, students received the intervention program, "A Team Against AIDS." Students in control group received the program, "Sexuality and First Aid." The study design was quasi-experimental because random assignment occurred at the classroom level and not the individual student level. The curriculum of the program covered a range of topics including knowledge specifically about HIV/AIDS, safe sex practices, and more general life skills. In addition, students were educated on sexuality in general and alternatives to heterosexuality. Teachers administered the 
program curriculum to students after being trained by the researchers. The program was administered over the course of 15 meetings in 2-hour increments throughout the semester. The workshops were participatory; that is, beyond lectures on topics like HIV transmission, students were engaged in role play on topics like communicating about condom use. There was also a reflective component.

Adolescents were assessed via a 174-item self-report questionnaire designed specifically for this study. Both pre- and post-test data were collected; the latter occurred 3 weeks following the end of the program. Results indicated that experimental group participants demonstrated gains in many attitudinal and knowledge measures. Those dependent variables included: self-knowledge of sexual situations, self-efficacy of condom use, norms surrounding condom use (other-focused), attitudes about condom use (self-focused), knowledge of HIV/AIDS, and communication about sex (with one's partner and more generally). The control group, by comparison, did not show a similar pattern of increases. Effect sizes indicated that the most substantial gains were made with respect to the attitudes towards condoms and knowledge about HIV/AIDS. The intervention, however, did not affect adolescent self-reported behavior, such as condom use. A 1-year follow-up of the program supported its effectiveness; the net increases (accounting for maturation) were strongest for knowledge and self-efficacy regarding condom use (Givaudan, Leenen, Van de Vivjer, Poortinga \& Pick, 2008).

\section{Vocational Training to Address Unemployment in Colombia}

Unemployment is another common challenge facing Latin American and Caribbean youth (Muggah, 2015). It is particularly problematic for youth in low income families (Attanasio, Kugler \& Meghir, 2008). A group of Latin American youth, the ninis (in Spanish ni estudia ni trabaja meaning "neither studying, nor working"), have received a great deal of attention in recent years. Neither students nor workers, ninis are a group of approximately 18 million Latin American 
youth (according to estimates from 2010) ages 15-24 who do not study or work (de Hoyos et al., 2016). The percentage of ninis varies greatly from country to country within the region, with Honduras and El Salvador topping the list. In general, there are higher rates of ninis in rural compared to urban areas. Ninis are not well educated, with only $43 \%$ of ninis having completed primary school. Approximately 12 million ninis are young women who have either started a new household with children of their own or are still living with their parents and are not actively looking for work. Young men make up the remaining onethird. The majority still live at home with their parents and nearly $50 \%$ are actively searching for work. Note that these descriptions counteract the stereotype of ninis as delinquents and criminal offenders (de Hoyos et al., 2016).

Although rates of youth unemployment have fallen in recent years (a 2.5\% decrease from 2005 to 2011), nearly 14\% of Latin American youth are still unemployed, which is two to four times the unemployment rates of adults (International Labour Organization [ILO], 2015; OIL, 2013). Disheartened by the lack of opportunity, some young people take to the streets to engage in a life of delinquency (Muggah, 2015). Many youth (approximately 60\%) who are employed work in the informal sector (e.g., as a maid or a gardener) making it more likely that they are earning low pay and face higher job insecurity (ILO, 2014). Only $28 \%$ of youth workers have a formal contract with their employer; those without this formal agreement are more vulnerable to mistreatment by employers. Recent initiatives have been undertaken by the ILO to assist youth in the region in finding jobs in the formal sector (ILO, 2015).

In Colombia, a randomized control trial was conducted to assess the effectiveness of a training program designed to address both employment and the earnings of at-risk youth (Attanasio et al., 2008). The program, Jóvenes en Acción [Youth in Action], was instituted by the Colombian government after a devastating economic recession hit the country in 2001 . This program was administered to over 80,000 youth in Colombia's seven largest cities over the course of 4 years and was 
designed for unemployed youth ages 18-25 in the lowest two deciles of the income distribution. The curriculum lasted 6 months in total and included 3 months each of classroom and on-the-job training (similar to an internship); there were training courses for a wide variety of careers including: taxi and bus drivers, cosmetologists, nurses' and physicians' assistants, and carpentry, plumbers and electricians' assistants. Although it varied slightly by program, participants were in the classroom for lectures approximately six hours each week. Trainees were paid a small stipend for their on-the-job training throughout the program.

Both men and women benefitted from the program, but for slightly different reasons. Women in the program were employed at higher rates compared to control group participants. In addition, they worked more days and hours than those in the control group and earned more for their work. Men, on the other hand, benefitted largely because they earned more for their work compared to the control group. In other words, men's employment rates were not affected by participation in the program. For both genders, earnings increases ( $8 \%$ for men and $18 \%$ for women) were limited to formal sector jobs. As noted above, holding a job in the informal sector is undesirable for a multitude of reasons; after participation in the program, participants were more likely to have a job in the formal sector and also to have an employee-employer contract for their work meaning employees had more rights and were better protected. The latter two findings were consistent for both men and women.

When comparing the Jóvenes en Acción program to similar programs in minority world countries (e.g., the U.S. and the U.K.), the Colombian initiative demonstrated unprecedented success. Attanasio et al. (2008) attribute the success of this program, at least in part, to the extensive hands-on experiences participants received during their internships. Moreover, the more intense the internship training, the greater the gains for participants. The private companies that sponsored the courses and internships were a combination of for-profit and notfor-profit companies. In conclusion, providing at-risk Colombian youth 
with both classroom-style and firsthand opportunities to learn their new trade yielded meaningful employment gains that will hopefully continue to benefit these youth and their families in the years to come.

\section{School Attendance and Health Clinic Visits in Nicaragua}

According to the Convention on the Rights of the Child (Office of the High Commissioner on Human Rights [OHCHR], 1989) education at both at the primary and secondary levels is a basic right to which children and adolescents are entitled. Encouragingly, primary and secondary school enrollment in the region has increased over the last 20 years, while dropout rates have decreased (Bassi, Busso \& Muñoz, 2014). When dropout does occur, it comes at more advanced educational levels. Although graduation rates have risen substantially since 1990 , especially in areas where the rates were particularly depressed, secondary school graduation rates are still low. There is also considerable within-country and within-region diversity. For example, disparities exist with respect to income level. Furthermore, some youth living within the same country receive higher quality education than others and some countries in the region of Latin America greatly outperform others.

According to Bassi et al. (2014) there are three critical reasons for the positive changes in Latin American secondary school enrollment since 1990. The first reason is straightforward; more children enroll in and graduate from primary school and those students then matriculate to secondary school. Between 2000 and 2010 in Panama, for example, the country experienced a dramatic growth in their primary to secondary school transition rate, which rose to $98.8 \%$ in 2010 from $64.5 \%$ in the year 2000 (United Nations Educational, Scientific, and Cultural Organization [UNESCO], 2014). As a whole, the region boasted a $93.5 \%$ average primary to secondary transition rate with only four of the 27 countries with available data yielding a rate below $90 \%$. The second reason is due to improved educational policies implemented in Latin America. These policies include better training for teachers (UNICEF, 2000), establishing a mandatory age for school 
enrollment, and implementing a decentralized approach to education (Bassi et al., 2014). The final reason is the success of incentive programs that encourage former students to return to school. The role of incentive programs in education will be discussed in more detail below (Gitter \& Barham, 2008).

Based on data from 10 countries in the region analyzed by UNESCO (2014), about half (53.5\%) of young people born between 1986 and 1990 (youth ages 20-24) completed secondary school in 2010 compared to a rate of $44.8 \%$ in youth born 10 years earlier. Thus, these numbers suggest that more young adults are graduating today from secondary school than they did in years past.

Despite those advances, a series of challenges remain. Educational quality is a concern with prevailing disparities with respect to urban versus rural setting and income. When the above UNESCO (2014) graduation rates are reconfigured to account for income level, those in the lower income categories report far lower graduation rates. In 2010, nearly $80 \%$ of youth from the wealthiest income quintile completed secondary school compared to $21 \%$ of those from the bottom quintile. This suggests that issues of disparity in educational quality and opportunity by income level must be rectified to elevate the low secondary school completion rates of the region as a whole.

Lastly, the enrollment and graduation rates of Latin American secondary school students lag behind those of the minority world (Bassi et al., 2014). The range of secondary school enrollment in Latin America spans from a low of 50\% to a high of $80 \%$ (UNESCO, 2014). One factor that may contribute to the variability in enrollment is the nation's Gross Domestic Product (GDP) with greater wealth associated with higher enrollment rates. Another important factor is related to students' performance (UNESCO, 2014). Failing a grade level and hence, failing to advance to the next grade on time, is associated with higher dropout rates (UNESCO, 2014). Unfortunately, the issue of grade failure has remained a consistent challenge for Latin American and Caribbean countries over the last several years with some countries actually experiencing an increase in fail rates (UNESCO, 2014). 
Access to basic health care is also a fundamental right to which children and adolescents are entitled (Convention on the Rights of the Child (OHCHR, 1989). Many of the health problems that Latin American and Caribbean youth face are specific to or more prevalent for their age group (Cunningham, McGinnis, García Verdú, Tesliuc \& Verner, 2008). For example, we see high rates of alcohol and drug use during this life stage. Adolescent pregnancy and consequences related to engaging in unprotected sex are also paramount concerns during adolescence. Recall that we discussed the prevalence of HIV/AIDS more specifically in an earlier section with respect to the interventions with Mexican youth (Givaudan et al., 2008; Givaudan et al., 2007) The picture becomes even more complex when we factor in the violent and oftentimes tragic outcomes of gang violence. As noted above, homicide is the leading cause of death for seven countries in the region (UNICEF, 2014) and nearly one-fifth of babies born to adolescents worldwide are born in Latin America and the Caribbean (WHO, 2014).

Although the threats to health outlined above oftentimes receive more attention from non-government organizations and the media, non-communicable diseases (NCDs) are a growing problem in Latin America (Baldwin, Kineda, Amato \& Nolan, 2013). By the year 2030, over $80 \%$ of deaths in the region will due to NCDs. In Latin America the top four NCDs are: tobacco use, excessive alcohol consumption, unhealthy diet, and a lack of adequate physical exercise (Baldwin et al., 2013). Oftentimes interventions for NCDs are reserved for adults, but adolescence is frequently the period in which tobacco use and unhealthy alcohol consumption are initiated, thus increasing the likelihood that a NCD will manifest later in life (Baldwin et al., 2013). Unhealthy eating and low levels of physical exercise probably develop even earlier in development (i.e., in childhood). Adolescence, though, is a period in which we can reinforce the benefits of a healthy lifestyle through interventions. Projections estimate that prevention programs could reduce the complications associated with NCDs by $50 \%$ or more (Baldwin et al., 2013). The rationale behind prevention programs 
is that it is more feasible to instill healthy habits in youth than it is change an unhealthy lifestyle in adults (Baldwin et al., 2013). Given the health risks facing Latin American youth, regular visits to doctors and health clinics are critical, both to prevent illness and to treat it when it occurs. Access to these facilities might be difficult depending on the young person's location, highlighting the need to make health clinics more accessible for youth and their families (Cunningham et al., 2008). Furthermore, it is important that health care facilities are prepared to provide care specifically to youth (Cunningham et al., 2008). Consistent with Bronfenbrenner's model and the idea that many of these risk factors are interrelated, parents with higher levels of education also tend to have healthier children (Grossman \& Kaestner, 1997). Although one might attribute this finding to a higher income, research suggests the relation is driven by the superior knowledge that educated parents possess regarding healthy living and the importance of making regular doctor's visits (Grossman \& Kaestner, 1997).

Results from intervention research suggest that they are effective in encouraging youth visits to health providers (WHO, 2006). In particular, interventions that include the availability of health services, for example, through mobile units, and services that are well-versed in the unique needs of youth (e.g., related to sexual and reproductive health) are particularly effective (WHO, 2006). Furthermore, outreach efforts that are widespread and include the entire community increase the demand for and use of health services (WHO, 2006). The latter finding supports Bronfenbrenner's systems theory in that youth needs are best understood within the context in which they live and that the people in those contexts shape and contribute to the young person's development.

To address the issues of school enrollment and regular doctor's visits, a conditional cash transfer program named the Social Safety Net (Red de Protección Social [RPS] in Spanish) was implemented in Nicaragua (Gitter \& Barham, 2008). Conditional cash transfer programs pay individuals or families a small sum of money if they continue to engage in the desired behavior(s). In the case of the RPS program, that 
money was specifically paid to the mothers in the household for evidence of school attendance. The mothers were compensated specifically (as opposed to fathers) because of the extensive literature that suggests that women are more likely to invest the money gained from cash transfer programs in their children's health and educational expenses than are men. The evaluation of the effectiveness of the RPS program was limited to educational outcomes. To analyze its effectiveness, 21 Nicaraguan communities were randomly selected to participate. An additional 21 communities served as a control group. The number of households, including the experimental and control groups, totaled more than 1120 . The program was successful such that youth in the experimental group did attend school at higher rates than their counterparts in the control group. In addition, the increased income allowed mothers to purchase healthier foods (e.g., milk) for their families.

\section{Tutoring program in Brazil to Address Secondary School Dropout Rates}

As described above, there are many challenges to receiving a secondary education in Latin America and the Caribbean. One such risk is school dropout, which is exacerbated by poverty (Inter-American Development Bank [IDB], 2016). For example, only $18.5 \%$ of Panamanian youth in the lowest income quantile graduate from secondary school compared to $75.4 \%$ in the highest income quintile. The same pattern holds across the region although the strength of that discrepancy between the lowest and highest quintiles varies. The urban-rural divide is also another concern with respect to dropout rates as graduation rates in urban areas are about $24 \%$ higher than those in rural areas (Bassi et al., 2014).

Youth leave their studies before completion for a variety of reasons. A primary one is terminating education in favor of joining the workforce (Zinny, 2013). For these young people, the need to support themselves and their families financially trumps staying in school. Some estimates suggest that the need to earn money accounts for between one-fourth and one-fifth of dropouts in the region (Zinny, 2013). An even larger 
percentage of cases (approximately 40\%) can be explained by boredom. Many students do not feel challenged in their classes and/or do not see how the material is applicable to their lives. Therefore, they do not see a need to continue with their studies. Another concern comes from future employers. Many in the private sector worry that young people will be ill-equipped to meet the challenges present in the $21^{\text {st }}$ century business world as they demand critical thinking, curiosity, and complex problem solving, among others (Zinny, 2013). Some are concerned that the (oftentimes low quality) education youth receive is not wellmatched to the skills they will actually need when working a future job (Bassi et al., 2014). In sum, both students and employers agree that the education young people receive may not match their current and future needs.

The Coca-Cola ${ }^{\circledR}$ Valued Youth Program was designed to decrease dropout among secondary school students (Montes, 2001). Initiated in the 1980s in the United States, high school students identified as at-risk for dropout are selected as tutors for primary school students. To better fit the structure of the Brazilian school system, students in the sixth-eighth grades tutored the younger children. As is oftentimes the case worldwide, age and grade level were not strongly correlated (a phenomenon called over-agedness; Montes, 2001). In the case of Brazilian schools, some of the tutors in this study were as old as 20 years of age $\left(M_{\text {age }}=15\right.$ years, range 13-20 years) and some of the first and second graders were age 10 or 11 . The Coca-Cola ${ }^{\circledR}$ Valued Youth Program is built on five pillars and involves not only the youth, but his/her parents. Those pillars include: "classes for student tutors, the tutoring sessions themselves [between the older and younger students], field trips, role modeling, and student recognition" (Montes, 2011, p. 2).

The program was evaluated using a mixed-methods design in two Brazilian schools (one in São Paolo and a second in Rio de Janeiro). Researchers assessed the program's effectiveness via focus groups and interviews from school personnel, parents, and the adolescent tutors themselves along with quantitative self-report measures. Fifty adolescent tutors participated and worked with 150 elementary school 
students over the course of the program. Focus group data suggested that participants made meaningful gains in behavior, relationships, and academics. Participant quantitative self-reports revealed gains on a multitude of domains including both attitudes (e.g., self-concept, future goals) and behaviors (e.g., attendance and academic performance). In the São Paulo school, the passing rate of the adolescent tutors rose from 61 to $94 \%$. In Rio de Janeiro, the rate was even more substantial rising to $96 \%$ from a pass rate of $60 \%$ pre-intervention. Participants also reported better dress and hygiene, relationships with parents, teachers, and classmates, and a greater interest in school and class activities. The tutored students also saw benefits from being tutored by the older students. The benefits paralleled those of the tutors and included an improved self-concept, better social skills at school, high academic achievement and interest in coursework, and improved dress and hygiene.

\section{Lessons Learned}

The interventions and programs reviewed above share a common purpose - to improve the lives of at-risk Latin American and Caribbean youth. Despite their common aim, these programs have achieved that goal by focusing on different challenges for youth in the region and by providing a wide variety of interventions. One clear difference among the programs is whether or not the youth personally participate in an intervention. In experiential programs, youth learn directly through active engagement. Of the programs reviewed in this chapter, youth personally participated in a) the non-violent horse handling workshops in Guatemala (Gibbons et al., 2016), b) an HIV/AIDS prevention program in Mexico (Givaudan et al., 2007; Givaudan et al., 2008), c) vocational training in Colombia (Attanasio et al., 2008), and d) the program to engage Brazilian adolescents as tutors for younger students (Montes, 2001). Although the mode of instruction varied from working with horses to role-playing about HIV/AIDS to on the 
job training to serving as tutors, the adolescents were active participants, engaging in programs and activities personally. In other cases, a structural change is implemented that impacts young people's lives indirectly. The extension of the school day in Chile (Berthelon \& Kruger, 2011) and the conditional cash transfer program in Nicaragua (Gitter \& Barham, 2008) were examples of structural changes. Youth did not participate in a personal, hands-on way, yet the changes directly affected their lives. In Chile, they were required to spend more time in school leaving less time for risky behavior. With the program in Nicaragua, school attendance increased and mothers had additional money to spend on healthy foods as a result of cash payments. This distinction is paralleled by Bronfenbrenner's $(1977,1979)$ micro and exosystems. Mircosystems are represented by programs with direct participation, while exosystems are reflected in programs that enact structural change.

A core similarity across all of the programs is that they provided youth an opportunity to engage in meaningful and productive activities. The vocational training program in Colombia is exemplary in this regard (Attanaiso et al., 2008). As participants in the program, youth completed both classroom and on the job training. As a result of the latter, young people gained valuable practical experiences that allowed them to achieve higher rates of employment and to make higher wages for their work. Adolescents in the HIV/AIDS program in Mexico were exposed to active learning experiences like role-playing (Givaudan et al., 2007; Givaudan et al., 2008). Through these activities they were able to practice how to communicate about sex and related issues like condom use. Even for the programs that were applied via structural change, youth were impacted indirectly in that they spent more time in educational activities (Berthelon \& Kruger, 2011; Gitter \& Barham, 2008).

Although not always explicitly measured in these interventions, selfefficacy may be an underlying factor contributing to the success of the programs. For example, in the non-violent horse training interventions, youth with little or no previous experience with equines learned how to handle a large animal without the use of violence (Gibbons et al., 2016). As described above, self-reported youth leadership increased at post-test 
perhaps because adolescents felt a sense of competence and success after the positive human-horse interaction. In the focus groups, many youth noted that they had greater confidence in their abilities to solve problems and engage in meaningful interactions with others after working with the horses.

The findings from the Brazilian tutoring program (Montes, 2001) parallel a long line of research from the United States that credits volunteer activities with reducing undesirable outcomes (Allen, Philliber, Herrling \& Kuperminc, 1997; Eccles \& Barber, 1999). For example, U.S. adolescent girls who contributed to society via volunteer work were less likely to get pregnant than girls who did not volunteer (Kirby, 2002). In another study, secondary school students in the U.S. who had volunteered were less likely to use alcohol and drugs than their counterparts who had not served as volunteers (Eccles \& Barber, 1999). For the students in Brazil, their increased efficacy was manifested in both positive attitudinal and behavioral changes (Montes, 2001). Thus, participating in these programs leaves youth with more confidence in their ability to positively impact their futures.

The central task of adolescence is often defined as identity development (Erikson, 1938). Along with that quest for identity comes the desire for adolescents' worth to be acknowledged (UNICEF, 2011). In other words, "Adolescents do not consider themselves as 'future adults', they want to be taken seriously now" (UNICEF, 2011, p. 9). Two of the programs that we have reviewed do an excellent job of addressing this primary adolescent need. The first is the HIV/AIDS program for Mexican youth as it arms young people with the tools to make their own wise decisions about sex and pregnancy (Givaudan et al., 2007; Givaudan et al., 2008). Thus, the underlying message is that adolescents currently possess the knowledge they need to make these personal decisions for themselves. Although they may need to communicate with adults about their questions or concerns, adolescents are competent and qualified to practice safe sex after completing the program.

The second program to foster adolescent self-worth is the horsehanding intervention in Guatemala (Gibbons et al., 2016). Through 
the workshops and series of exercises, young people are empowered, such that they believe they can be leaders in their classroom, in their homes, and with their friends. The interactions with the horses provide concrete evidence of their leadership ability. Both programs emphasize that young people are valued and important. Furthermore, they do not need to wait until adulthood to be recognized and appreciated for the skills and abilities they possess.

It is important to note that changes implemented at various levels of Bronfenbrenner's $(1977,1979)$ theory can be successfully applied to address similar problems. For example, the Chilean initiative was specifically focused on the decrease in adolescent pregnancy (Berthelon \& Kruger, 2011) and the Mexican program was designed to reduce the spread of HIV/AIDS (Givaudan et al., 2007; Givaudan et al., 2008), but both were pioneered to promote safer sexual behavior in adolescents. These efforts addressed different levels of the young person's environment. Extending the school day in Chile was a change made at the exosystem level. Youth did not participate personally in shaping this decision, yet their daily lives were significantly impacted by the initiative's consequences (Berthelon \& Kruger, 2011). In contrast, Mexican secondary school students personally learned from a training course about effective methods for HIV/AIDS intervention (Givaudan et al., 2007; Givaudan et al., 2008). Recall facilitators' use of role-playing to help participants practice communication about sex, a conversation that is oftentimes difficult for young people to have with their partners and their parents. Both the structural and experiential approaches were effective with respect to the studies' outcomes. Given that youth development is best understood in the context of their multilevel environment, we propose that interventions for at-risk youth should be exacted at all environmental levels to enhance effectiveness and to accurately mirror the way youth behaviors and attitudes are shaped and influenced.

On a related note, two of the interventions we described demonstrated how families were involved in or affected by the intervention, providing further support for Bronfenbrenner's (1977,1979) model. 
Mothers, for instance, played a critical role in the conditional cash transfer program that resulted in higher school attendance for school youth in Nicaragua (Berthelon \& Kruger, 2011). Of course, mothers represent an important influence in their children's lives and consequently, are a critical microsystem that significantly contributes to their development. Thus, it is not surprising that their involvement was key to the intervention's success.

Family members of Guatemalan participants in the horse handling intervention noted a ripple effect (Gibbons et al., 2016). Some family members reported that the youth tried to teach some of the workshop content to family members to help deescalate personal conflicts or to better manage stress. They also applied their new leadership skills to their own households. Participants' ability to better communicate about their feelings and frustrations resulted in stronger relationships with friends and family members. In addition, Brazilian adolescents reported similar relationship improvements after serving as tutors (Montes, 2001). Therefore, those results suggest that although the adolescents themselves may be the direct participants in interventions, they apply what they learn to other contexts allowing others to benefit from the adolescents' post-intervention growth.

\section{Conclusion}

In sum, the results of these interventions reveal that although Latin American and Caribbean youth face great challenges, they also possess remarkable potential. The risks are varied and the methods used to address them are also diverse, both to the degree to which the youth themselves are involved and in the approach of the actual programs. However, comparisons of the interventions reviewed here suggest that these diverse paths can yield similar benefits. For example, the structural change of extending the school day in Chile (Berthelon \& Kruger, 2011) and the participatory HIV/AIDS prevention program in Mexico (Givaudan et al., 2007; Givaudan et al., 2008) both revealed benefits 
for adolescent sexual and reproductive health. Furthermore, interactions with horses (Gibbons et al., 2016) and role-playing about sex communication (Givaudan et al., 2007; Givaudan et al., 2008) suggested gains for youth self-efficacy. Just as Bronfenbrenner (1977, 1979) argued that there is no one influence on development, there are multiple effective routes to enacting positive change in the lives of at-risk youth. These conclusions should be encouraging for those who work with young people, both as practitioners and as researchers. In designing future programming, researchers should keep in mind the core elements of experimental design by including a control and an experimental group and by employing random assignment. Mixedmethods design and the inclusion of multiple informants also enhance the quality of the intervention and its evaluation. We conclude that interventions can help foster well-being and create a positive future for Latin American and Caribbean youth.

\section{References}

Allen, J. P., Philliber, S., Herrling, S. \& Kuperminc, G. P. (1997). Preventing teen pregnancy and academic failure: Experimental evaluation of a developmentally based approach. Child Development, 68, 729-742. https://doi.org/10.2307/1132122

Attanasio, O., Kugler, A. \& Meghir, C. (2008). Training disadvantaged youth in Latin America: Evidence from a randomised trial. Retrieved from http://www.ifs.org.uk/edepo/wps/ewp0801.pdf Avert. (2016). HIV and AIDS in Latin America regional overview. Retrieved from http://www.avert.org/professionals/hiv-aroundworld/latin-america/overview. https://doi.org/10.3386/w13931

Baldwin, W., Kineda, T., Amato, L. \& Nolan, L. (2013). Noncommunicable diseases and youth: A critical window of opportunity for Latin America and the Caribbean. Retrieved from http://www.prb.org/pdf13/noncommunicable-diseaseslatin-america-youth-policybrief.pdf 
Bassi, M., Busso, M. \& Muñoz, J. S. (2014). Is the glass half empty or half full? Enrollment, graduation, and dropout rates in Latin America. Retrieved from http://www.iadb.org/en/research-anddata/publication-details,3169.html?pub_id=IDB-WP-462

Berthelon, M. E. \& Kruger, D. I. (2011). Risky behavior among youth: Incapacitation effects of school on adolescent motherhood and crime in Chile. Journal of Public Economics, 95, 41-53. https:// doi.org/10.1016/j.jpubeco.2010.09.004

Bronfenbrenner, U. (1977). Toward an experimental psychology of adolescent development. American Psychologist, 32, 513-531. https://doi.org/10.1037/0003-066X.32.7.513

Bronfenbrenner, U. (1979). The ecology of human development. Cambridge, MA: Harvard University Press.

Bronfenbrenner, U. (2005). Ecological models of human development. In M. Gauvain \& M. Cole (Eds.), Readings on the Development of Children (pp. 3-8). New York: Worth Publishers.

Cárdenas, M., de Hoyos, R. \& Székely, M. (2011). Ideal youth in Latin America: A persistent problem in a decade of prosperity. Retrieved from https:/www.brookings.edu/wp-content/ uploads/2016/06/Idle-Youth-in-Latin-America_FINAL.pdf

Chein, J., Albert, D., O’Brien, L., Uckert, K. \& Steinberg, L. (2011). Peers increase adolescent risk taking by enhancing activity in the brain's reward circuitry. Developmental Science, 14(2), F1-F10. https://doi.org/10.1111/j.1467-7687.2010.01035.x

Cunningham, W., McGinnis, L., García Verdú, R., Tesliuc, C. \& Verner, D. (2008). Youth at risk in Latin America and the Caribbean. Washington, D.C.: The World Bank. https://doi. org/10.1596/978-0-8213-7520-4

de Hoyos, R., Rogers, H., Székely, M. (2016). Out of school and out of work: Risk and opportunities for Latin America's ninis. Retrieved from https://openknowledge.worldbank.org/bitstream/handle/ 10986/22349/K8318.pdf? sequence=8\&isAllowed $=y$

Eccles, J. S. \& Barber, B. L. (1999). Student council, volunteering, basketball, or marching band: What kind of extracurricular 
involvement matters? Journal of Adolescent Research, 14, 10-43. https://doi.org/10.1177/0743558499141003

Enamorado, T., López-Calva, L. F., Rodríguez-Calaván, C. \& Winkler, H. (2014). Income inequality and violent crime: Evidence from Mexico's drug war. https://doi.org/10.1596/1813-9450-6935

Fries, L., Grogan-Kaylor, A., Bares, C. B., Han, Y. \& Delva, J. (2013). Gender differences in predictors of self-reported physical aggression: Exploring theoretically relevant dimensions among adolescents from Santiago, Chile. International Perspectives in Psychology, 2, 255-268. https://doi.org/10.1037/a0034533

Gibbons, J. L., Cunningham, C. A., Paiz, L., Poelker, K. E. \& Chajón, A. (2016). 'Now, he will be the leader of the house': An equine intervention with at-risk Guatemalan youth. International Journal of Adolescence and Youth. Advance online publication. https://doi.org/10.1080/02673843.2016.1202844

Gil, L. A., Kwon, K., Good, L. K. \&, Johnson, L. W. (2012). Impact of self on attitudes toward luxury brands among teens. Journal of Business Research, 65, 1425-1433. https://doi.org/10.1016/j. jbusres.2011.10.008

Gitter, S. R. \& Barham, B. L. (2008). Women's power, conditional cash transfers, and schooling in Nicaragua. The World Bank Economic Review, 22, 271-290. https://doi.org/10.1093/wber/lhn006

Givaudan, Leenen, I., M., van de Vivjer, F. J. R., Poortinga, Y. H. \& Pick, S. (2008). Longitudinal study of a school based HIV/AIDS easrly prevention program for Mexican adolescents. Psychology, Health \& Medicine, 13, 98-110. https://doi. org/10.1080/13548500701295256

Givaudan, M., van de Vivjer, F. J. R., Poortinga, Y. H., Leenen, I. \& Pick, S. (2007). Effects of a school-based life skills and HIVprevention program for adolescents in Mexican high schools. Journal of Applied Social Psychology, 37, 1141-1162. https://doi. org/10.1111/j.1559-1816.2007.00206.x

Grossman, M. \& Kaestner, R. (1997). The effects of education on health. In J. R. Behrman \& N. Stacey (Eds.), The social benefits 
of education, (pp. 69-124). Ann Arbor, MI: The University of Michigan Press.

Imbusch, P., Misse, M. \& Carrión, F. (2011). Violence research in Latin America and the Caribbean: A literature review. International Journal of Conflict and Violence, 5, 87-154.

Inter-American Development Bank. (2016). High school graduation rates in Latin America. Retrieved from http://www.iadb.org/ en/topics/education/infographic-high-school-graduation-ratesin-latin-america, $7110 . \mathrm{html}$

International Labour Organization. (2014). Unemploymnet and informality beset Latin American youth. Retrieved from http://www. ilo.org/global/about-the-ilo/newsroom/news/WCMS_235661/ lang--en/index.htm

International Labour Organization. (2015). Promoting formal employment among youth: Innovatice experiences in Latin America and the Caribbean. Retrieved from http://www.ilo.org/wcmsp5/ groups/public/---americas/---ro-lima/documents/publication/ wcms_361990.pdf

Keeling, L. J., Jonare, L., Lanneborn, L. (2009). Investigating horsehuman interactions: The effect of a nervous human. The Veterinary Journal, 181, 70-71. https://doi.org/10.1016/j.tvjl. 2009.03.013

Kirby,D.(2002).Effectiveapproachesto reducingadolescentunprotected sex, pregnancy, and childbearing. The Journal of Sex Research, 39, 51-57. https://doi.org/10.1080/00224490209552120

Montes, F. (2001). Coca-Cola Valued Youth Program in Brazil: Valuing youth across different cultures. Intercultural Development Research Association Newsletter, 1-5. Retrieved from http://www.idra.org/IDRA_Newsletter/January_2001_Self_ Renewing_Schools_Leadership/Coca-Cola_Valued_Youth_ Program_in_Brazil\%3A/

Muggah, R. (2015, October 12). Latin America’s poverty is down, but violence is up. Why? Americas Quarterly. Retrieved from http:// 
www.americasquarterly.org/content/latin-americas-povertydown-violence-why

Munyo, I. (2013). Youth crime in Latin America: Key determinants and effective public policy responses. Retrieved from https://www. brookings.edu/wp-content/uploads/2016/06/Youth-Crime-inLatin-America-Revised.pdf

Murray, M. (2014). Organized crime, gangs make Latin America most violent region. Retrieved from http://www.nbcnews.com/ news/world/organized-crime-gangs-make-latin-america-mostviolent-region-n83026

Office of the High Commissioner on Human Rights. (1989). Convention on Rights of the Child. Retrieved from http:/www.ohchr. org/en/professionalinterest/pages/crc.aspx

Organización Internacional del Trabajo. (2013). Trabajo decente y juventud en América Latina: Politica para la acción [Decent work and youth in Latin America: Policies for action]. Retrieved from http://www.ilo.org/wcmsp5/groups/public/---americas/--ro-lima/documents/publication/wcms_235577.pdf

Pick de Weiss, S., Aguilar, J., Rodríguez, G., Vargas, E., Reyes, J., Collado, M. E. et al. (1988). Planeando tu vida: Nuevo programa de educación sexual para adolescentes [Planning your life: A new sexual education program for adolescents (3rd ed.)]. Mexico City, Mexico: Planeta.

Rojas-Flores, L., Herrera, S., Currier, J. M., Lin, E. Y., Kulzer, R. \& Foy, D. W. (2013). "We are raising our children in fear": War, community violence, and parenting practices in El Salvador. International Perspectives in Psychology, 2, 269-285. https://doi. org/10.1037/ipp0000009

Román, M. \& Murillo, F. J. (2011). Latin America: School bullying and academic achievement. Cepal Review, 104, 37-53.

Smith, A. V., Proops, L., Grounds, K., Wathan, J. \& McComb, K. (2016) Functionally relevant responses to human facial expressions of emotion in the domestic horse (Equus caballus). Biology Letters, 12: 20150907. https://doi.org/10.1098/rsbl.2015.0907 
UN AIDS (2012). Young people living with HIV in Latin America make their voices heard. Retrieved from http://www. unaids.org/en/resources/presscentre/featurestories/2012/ october/20121018npyconsultation

UN AIDS (2015). How AIDS changed everything. MDG 6: 15 years, 15 lessons of hope from the AIDS response. Retrieved from http:// www.unaids.org/sites/default/files/media_asset/MDG6Report_ en.pdf

UNICEF. (2000). Secondary education in Latin America and the Caribbean: The challenge of growth and reform. Retrieved from http://www.unicef.org/lac/Secondary_education(1).pdf

UNICEF (2007). Teenage motherhood in Latin America and the Caribbean: Trends, problems and challenges. Retrieved from http://www.unicef.org/lac/desafios_Nro4_eng_Final(1).pdf

UNICEF (2008a). Children and HIVIAIDS in Latin America and the Caribbean. Retrieved from http://www.unicef.org/lacl Challenges7_Ing.pdf

UNICEF (2008b). El estado de la Infancia de América Latina y el Caribe 2008. [The state of Latin American and Caribbean Children 2008]. Retrieved from http://www.unicef.org/spanish/publications/index_45087.html

UNICEF (2011). The state of the world's children 2011: Adolescence: An Age of Opportunity. https://doi.org/10.18356/7f132111-en

UNICEF (2014). Hidden in plain sight: A statistical analysis of violence against children. Retrieved from http://www.unicef. org/publications/index_74865.html

UNICEF (2016). Estado mundial de la Infancia 2016: Una oportunidad para cada niño [State of the world's children 2016: A fair chance for every child]. https://doi.org/10.18356/0cdb393b-es

UNICEF (n.d.). Fast facts on adolescents and youth in Latin America and the Caribbean. Retrieved from www.unicef.org/media/files/ Fast_facts_EN.doc

United Nations (2003). Juvenile delinquency. Retrieved from http:// www.un.org/esa/socdev/unyin/documents/ch07.pdf 
United Nations Development Programme (2013). Citizen security with a humanface:EvidenceandproposalsforLatinAmerica. Retrievedfrom http://www.latinamerica.undp.org/content/dam/rblac/docs/ Research\%20and\%20Publications/IDH/UNDP-RBLACHDRLatAmExecSummary2013.pdf

United Nations Educational, Scientific, and Cultural Organization (2014). Regional report about education for all in Latin American and the Caribbean. Retrieved from http://www.unesco.org/new/ fileadmin/MULTIMEDIA/HQ/ED/ED_new/pdf/LAC-GEM2014-ENG.pdf

United Nations Population Fund (2013). Adolescent pregnancy: A review of the evidence. Retrieved from https://www.unfpa.org/ sites/default/files/pub pdf/ADOLESCENT\%20PREGNANCY_ UNFPA.pdf

Vygotsky, L. S. (1978). Mind in society: The development of higher psychological processes. Cambridge, MA: Harvard University Press.

World Health Organization (2006). Preventing HIVIAIDS in young people. A systematic review of the evidence from developing countries. Retrieved from http://www.unicef.org/aids/files/ PREVENTING_HIV_AIDS_IN_YOUNG_PEOPLE_A_ SYSTEMATIC_REVIEW_OF_THE_EVIDENCE_FROM_ DEVELOPING_COUNTRIES_WHO_2006.pdf

World Health Organization (2014). Adolescent pregnancy. Retrieved from http:/www.who.int/mediacentre/factsheets/fs364/en/

Zinny, G. S. (2013). Latin America's dropout crisis. Retrieved from http://www.atlanticcouncil.org/blogs/new-atlanticist/latinamerica-s-drop-out-crisis

Received: 07 September, 2016 Revised: 07 April, 2017 Accepted: 17 April, 2017 